\title{
DISCUSSIE
}

\section{Pacificatie in de nasleep van aanslagen en militante strijd}

\author{
Beperkte potentie van herstelrecht
}

Bas van Stokkom

Na de aanslagen in Parijs en Brussel (voorjaar 2015) schreef Lode Walgrave (2015) in dit tijdschrift dat de massale Je suis Charlie-betoging in Parijs een diepgaande herstellende betekenis had. De verwanten van de directe slachtoffers kregen immers indrukwekkende steunbetuigingen. Walgrave zette uiteen dat op terroristische aanslagen een krachtig afwijzend antwoord dient te komen. Begrip en dialoog lijken niet mogelijk na zulke verschrikkelijke gebeurtenissen. Maar hij betoogde ook dat op termijn herstelgerichte ontmoetingen de moeite van het proberen waard zouden zijn, omdat die gesprekken een helende werking kunnen hebben.

Ook hersteldenker Theo Gavrielides ziet kansen voor herstelgerichte benaderingen in die doornige context. ${ }^{1}$ De extremistische ideologie die terroristen in de ban heeft, moet niet als een 'vreemd virus' worden opgevat, benadrukt hij, maar is mede een product van onze samenleving waarin sommige groepen bepaald niet respectvol worden bejegend. In plaats van terroristen de oorlog te verklaren en hen levenslang op te sluiten, zou het zinvol kunnen zijn de 'terrorist within' te aanschouwen en hen aan te spreken op hun verantwoordelijkheid.

In landen als Columbia die al langer worstelen met politiek geweld en aanslagen worden de leiders van voormalige gewelddadige groepen niet bij voorbaat voor het gerecht gesleept, maar worden veel pogingen gedaan om partijen bijeen te brengen en vredesopbouw te bevorderen (Pearson, 2017). Dergelijke initiatieven zijn in veel opzichten wenselijk en verdienen aanmoediging.

Het Radicalisation Awareness Center van de EU heeft in dat verband onlangs kennis bijeengebracht over pacificatieprojecten in landen die te maken hebben met een gepolariseerd klimaat ten gevolge van lange perioden van geweld (onder andere Baskenland, Noord-Ierland en voormalig Joegoslavië). Volgens het Centrum kunnen herstelrechtelijke initiatieven bijdragen aan die pacificatie en in het

1 Gavrielides, T. (2016) The Terrorist Within: From a Restorative Lens. Justice Report, 32(1) (Special International Issue on Terrorism). Geraadpleegd via http://yeip.org/wp-content/uploads/ 2017/05/The-Terrorist-Within-From-A-Restorative-Lens.pdf. 
bijzonder zouden slachtoffers en nabestaanden van het geweld inspiratie kunnen bieden en de weerbaarheid tegen gewelddadig extremisme kunnen vergroten. ${ }^{2}$

Niettemin is het de vraag of het herstelrecht de geëigende sociale institutie is om bij deze pacificerende taken voorop te lopen. Reparatie is immers slechts één van de aspecten die tijdens vredesopbouw een rol spelen. Bovendien impliceert vredesopbouw een democratisch vernieuwingsproces, waarbij veel druk wordt uitgeoefend op politici, bestuurders en beleidsmakers om hervormingen door te voeren. In deze bijdrage zal ik enkele kritische vragen opwerpen bij herstelrechtelijke ambities in de 'politieke arena' van vredesopbouw.

\section{Het apolitieke discours van herstelrecht}

In een interessante overzichtsstudie - waarbij en passant ook het 'Baskische probleem' wordt besproken - betoogt Margarita Zernova (2019) dat pleitbezorgers van herstelgerichte aanpakken in de context van politiek gemotiveerd geweld te snel de assumpties rondom terrorismebestrijding overnemen. Daarbij speelt dat 'terrorisme' vaak een label is om de tegenpartij als 'monsterlijk' of 'staatsgevaarlijk' af te schilderen. Bovendien is onduidelijk wat nu eigenlijk hersteld dient te worden. Herstel van orde en rust die door de aanslagen zijn verstoord? In dat geval wordt de politieke realiteit ontkend dat verzetsgroepen zich vaak keren tegen structureel sociaal onrecht en gelijke toegang en eerlijke verdeling pogen te bewerkstelligen.

In dat verband spreekt het 'Baskische probleem' boekdelen. Volgens de Spaanse overheid is ETA-engagement illegitiem en is staatsrepressie gerechtvaardigd, omdat die de democratie beschermt. Volgens Zernova heeft het Spaanse justitiebeleid een hiërarchie van slachtoffers gecreëerd: ETA-slachtoffers krijgen het meest bescherming, slachtoffers van politie- en justitieoptreden krijgen minder of zelfs helemaal geen bescherming. In deze context liggen herstelgerichte antwoorden niet meteen voor de hand. Immers, de herstelrechtelijke procedures die de overheid inzette om het ETA-geweld te bespreken, werden door veel ex-ETA-militanten als vernederend ervaren, onder meer omdat zij hun politieke denkbeelden moesten afzweren. Dat roept de vraag op of ex-militanten zich wel moeten verontschuldigen voor hun politieke idealen. Niet verwonderlijk dat de herstelrechtelijke initiatieven verdeeldheid teweegbrachten tussen de ETA-gevangenen. Daarbij speelde mee dat politiemensen die ETA-verdachten hadden misbruikt en gemarteld vrijuit gingen. Op de achtergrond speelde ook de Franco-erfenis mee: politiemensen en militairen die grove misdaden begingen ten tijde van de dictatuur werd volledige amnestie verleend. Om deze redenen wijzen kritische waarne-

2 Het gaat om de papers 'The role of restorative justice in preventing and responding to violent extremism' en 'The role of victims in strengthening social cohesion after a period of violence'. https://ec.europa.eu/home-affairs/sites/homeaffairs/files/what-we-do/networks/

radicalisation_awareness_network/ran-papers/docs/ran_rvt-

exit_role_of_restorative_justice_dublin_3-4_122019_en.pdf. En: https://ec.europa.eu/homeaffairs/sites/homeaffairs/files/what-we-do/networks/radicalisation_awareness_network/aboutran/ran-rvt/docs/ran_rvt_the_role_of_victims_bilbao_21062019_en.pdf. 
mers van het Baskisch conflict erop dat vreedzaam overleg binnen het frame van terrorisme onmogelijk is: die taal eist een 'totale overwinning' voor de Spaanse democratie en een nederlaag voor de 'terroristen' (Zernova, 2019: 5-12; zie ook Zernova, 2017).

Zernova vraagt zich af of het a priori afwijzen van achterliggende politieke ideeën van geradicaliseerde groepen wel in de rede ligt. Wordt het politieke debat over de betekenis en achterliggende oorzaken van terroristische geweld hierdoor niet geblokkeerd? In dat verband verwijst ze naar Nils Christie (2013) en zijn frase 'there are dangers in words'. Herstelgerichte pleitbezorgers neigen ertoe strafrechtelijke manieren van denken over te nemen, terwijl wettelijke bepalingen en de handhaving daarvan vaak een probleem vormen. Zijn advies is bekend: spreek in termen van conflicten.

Volgens Zernova zouden we vredesgesprekken meer in termen van een politiek conflict moeten zien. Een door de Spaanse staat opgelegde en gepromote 'waarheid' over het verleden hindert bij voorbaat de dialoog. Zo bezien is er in complexe postconflict-contexten geen plaats voor een simplistisch onderscheid tussen groepen slachtoffers en daders. Ook het lijden dat door de overheid is teweeggebracht, moet worden erkend. Hoe dat ook zij, besluit Zernova, er bestaat geen morele consensus over de gewelddadige gebeurtenissen. Het opleggen van één enkele versie van het verleden staat verzoening in de weg. Bovendien zouden pleitbezorgers van herstelrecht zich niet moeten laten gebruiken om de voorgegeven status quo te 'herstellen'. In dat opzicht is 'herstel' een apolitieke term die de blik afwendt van achterliggende problemen als sociale deprivatie, discriminatie en machtsongelijkheid.

In plaats van herstelgerichte antwoorden te bieden ligt het volgens Zernova meer voor de hand te streven naar politieke verzoening en het opzetten van bredere maatschappelijke projecten voor herinnering van historisch onrecht, waarbij aandacht is voor misdaden en aangedaan leed van beide kanten.

De analyse van Zernova noodzaakt tot kritische reflectie. De gebruikelijke reacties op terroristisch geweld - onderdrukken en langdurig opsluiten - komen in een ander daglicht te staan. Haar analyse leert dat definities van terrorisme de uitkomst zijn van politieke strijd en dat repressieve antwoorden voor sommige groepen militanten juist een prikkel vormen om zich als 'terrorist' op te werpen. Tijdens het optreden van de Spaanse politie en justitie in Catalonië in 2019 zien we overigens veel van deze ideologische reflexen terug. De reactie van de nationale overheid is louter legalistisch: politieke tegenstanders zijn 'terroristen' en er is geen millimeter ruimte om probleemgericht te communiceren. Er wordt een situatie gecreëerd waarin degenen die het etiket terrorist krijgen opgeplakt, ervan overtuigd raken dat terrorisme wel eens een legitieme tactiek zou kunnen zijn. Deze reflexen zijn overigens ook kenmerkend voor reacties van West-Europese landen op terroristische aanslagen. Islam en radicalisering worden snel met elkaar vereenzelvigd en er worden problematische labels zoals 'misdadig' en 'virus' op moslimgemeenschappen geplakt. Achterliggende structurele problemen zoals ongelijke behandeling van minderheden worden ontkend of getrivialiseerd (zie de bijdrage van Aertsen en collega's in dit nummer). 


\section{De postconflict-context: een bredere lens voor herstelrecht?}

Kerry Clamp (2016, 2019; Clamp \& Doak, 2012) heeft veel studie gemaakt van de potenties van herstelrecht in postconflict-situaties. Ze erkent dat herstelrecht om meerdere redenen moeilijk inpasbaar is in die contexten. Ten eerste zijn bij alle strijdende partijen slachtoffers gevallen, vaak ook door onderlinge conflicten binnen groepen. In die context is het onduidelijk wie nu eigenlijk slachtoffer of dader is. Ten tweede zijn geweldsdaden dikwijls niet los te maken van de bredere politieke omgeving, zoals de ongelijke toegang tot politieke macht en ongelijke verdeling van hulpbronnen. Bredere oorzaken van het conflict komen tijdens herstelrechtelijke gesprekken niet in het vizier, enkel de incidenten. Ten derde is de overheid vaak medeplichtig aan geweld tegen burgers of de overheid gedoogt geweld tegen bepaalde bevolkingsgroepen. Hoe de staat dan positioneren in herstelbesprekingen? Ten vierde volstaat reparatie niet om de wederopbouw van het land ter hand te nemen en de levensvoorwaarden van burgers te versterken. Structurele sociale problemen blijven een rol spelen en reparatie doet daar weinig aan af.

Ondanks deze realiteiten doet Clamp een poging om herstelrechtelijke concepten breder toepasbaar te maken, ook in contexten van transitional justice. Zij wil de lens van herstelrecht aanzienlijk verbreden: herstelrecht zou een toekomstgericht pad moeten bewandelen en bevolkingsgroepen bij elkaar kunnen brengen. De aandacht verschuift van het achterhalen van waarheid in het verleden naar het creëren van een duurzame toekomst en naar sociale, collectieve behoeften. In haar woorden: 'Our starting point should not be seeking accountability, but rather addressing needs' (2019: 5). Herstelrecht zou als frame kunnen dienen om instituties te creëren die tegemoet kunnen komen aan behoeften van alle stakeholders.

Ik meen dat deze missie herstelrecht verre boven de pet gaat. Het veronderstelt dat herstelrechtelijke instituties bij machte zijn de uitvoering van vredesopbouw op regionaal of nationaal niveau op zich te nemen. Bovendien, herstelrecht mist domweg de concepten om vorm te geven aan die toekomstgerichte opbouw. Er is een ander soort engagement vereist. Zo ontkom je er in de context van vredes- en samenlevingsopbouw niet aan politieke idealen uit dragen en onder andere aan te geven hoe rechtsbescherming en democratische kernwaarden versterkt kunnen worden en hoe zorg voor kwetsbare groepen gestalte kan krijgen. Bovendien worden machtsvorming en onderhandelingskunst gevraagd om netelige kwesties op te lossen, waaronder de hervorming van de politie, ontwapening van paramilitaire organisaties en bestrijding van corruptie in politieke lichamen (Van Stokkom, 2016).

\section{Gepaste ambities en een passend werkveld}

Wat vermag herstelrecht dan wel te bewerkstelligen? In een kernachtig betoog over beginselen en reikwijdte van herstelrecht - getiteld: Restorative Justice is not a panacea against all social evils - wijst Lode Walgrave (2017) erop dat herstelrecht 
geen strategieën in huis heeft om de achterliggende factoren van misdaad en onveiligheid te bestrijden, waaronder sociale ongelijkheid en discriminatie (zie o.a. Cunneen, 2010). In dat opzicht zijn herstelrecht en strafrecht - ondanks alle verschillen - aan elkaar verwant.

Walgrave opteert voor een realistische kijk: herstelrecht is slechts één van de vele sociale instituties die het sociale leven in goede banen leiden. Ambities om van herstelrecht een voertuig te maken om sociale ongelijkheden te corrigeren zijn niet realiseerbaar. Verder is de term herstelrecht voor velerlei uitleg vatbaar. Zo kan 'herstel' ook worden geduid in termen van 'terug naar een toestand van harmonie en vrede'. Maar hoe kun je in zo'n visie machtsongelijkheden en klassenverschillen een plek geven? Sterker, herstelrecht lijkt bij te dragen aan die verschillen. Behoorlijk wat onderzoekers hebben aangetoond dat vooral middenklassen gebruikmaken van bemiddelingsgesprekken, terwijl slachtoffers en daders uit marginale sociale milieus veelal meteen met strafrechtelijke instanties te maken krijgen (voor een recent onderzoek, zie Willis, 2020).

Walgrave pleit voor een ingeperkt werkterrein. Hoewel herstelrecht deel uitmaakt van een bredere sociale beweging voor rechtvaardigheid en vrede, zou het zich enkel dienen te focussen op de constructieve afdoening van 'criminaliseerbare zaken'. Herstelrechtelijke gesprekken moeten duidelijk onderscheiden worden van gesprekken over onrecht of toegebrachte schade die niet als (potentiële) 'inbreuken' kunnen worden gekwalificeerd. Denk bijvoorbeeld aan conflicten over verdelende rechtvaardigheid. De conflicten die in een herstelrechtelijk domein worden bijgelegd, hebben dus - niet anders dan in het domein van het strafrecht - betrekking op aangebrachte schade en aangetaste waardigheid. In Walgraves optiek maakt herstelrecht deel uit van 'misdaadrecht' en hij poogt dat recht maximaal in het teken van reparatie te plaatsen, rekening houdende met factoren die sociale re-integratie in de weg staan. Het strafrecht is te veel afgestemd op formele gelijkheid van individuen: recht doen zou niets te maken hebben met de specifieke sociale achtergronden van individuele daders, of ze nu uit de bourgeoisie komen of een getto.

Ik onderschrijf deze analyse. Herstelrecht is geen panacee om alle sociale problemen op te lossen. Het bestrijden van sociaal onrecht en het bevorderen van respectvolle omgang zijn zaken die alle maatschappelijke instituties aangaan. 'Believing that restorative justice could address all social conflicts and injustices is unworldly. It makes restorative justice vulnerable to being caricatured as "evangelism" or "doing good", and loss of credibility' (Walgrave, 2017: 107).

We moeten het hervormingsgezinde potentieel van herstelrecht dus niet overschatten. Vredesopbouw bestrijkt een veel breder werkterrein, inclusief versterking van sociale rechtvaardigheid, en dat werkterrein is onvermijdelijk politiek van aard, inclusief machtsvorming, lobbyen en onderhandeling. Dat hoeft uiteraard niet te betekenen dat herstelrechtelijke pleitbezorgers blind zouden moeten blijven voor onrecht en sociale problemen. Integendeel, aansluiting op projecten rondom samenlevingsopbouw is wenselijk, zoals 'vreedzame wijk'-initiatieven in Utrecht.

Maar herstelrechtelijke procedés hebben hun eigen, typerende plaats in vredesopbouw: zij voorzien primair in morele genoegdoening. Dat geldt ook voor gesprek- 
ken in het kader van de-radicalisering. Zodra opbouwvraagstukken op tafel komen, wordt het herstelrechtelijke domein verlaten en doet de politiek zijn intrede. In de nasleep van aanslagen worden hervormers sowieso genoodzaakt om de repressieve reflexen van de overheid en de problematische frames die in het publieke debat worden gebruikt, te kritiseren. Dat geeft aan dat een herstelrechtelijke benadering slechts een beperkte rol kan spelen in het proces van de-radicalisering. Het onderzoek naar de radicaliseringshaarden in Brussel en Verviers waarover Ivo Aertsen en zijn medeauteurs in dit nummer rapporteren, is daarvan een goed voorbeeld.

\section{Literatuur}

Christie, N. (2013) Words on Words. Restorative Justice. An International Journal, 1(1), 15-19.

Clamp, K. (2016) Restorative Justice as a Contested Response to Conflict and the Challenge of the Transitional Context: An Introduction. In: K. Clamp (ed.), Restorative Justice in Transitional Settings. London: Routledge, 15-36.

Clamp, K. (2019) Transforming Restorative Justice for Transitional Settings. In: M. Natarajan (ed.), International and Transnational Crime and Justice. Cambridge University Press, 456-460.

Clamp, K. \& J. Doak (2012) More than Words: Restorative Justice Concepts in Transitional Justice Settings. International Criminal Law Review, 12(3), 339-360.

Cunneen, C. (2010) The Limitations of Restorative Justice. In: C. Cunneen \& C. Hoyle, Debating Restorative Justice. Oxford: Hart.

Pearson, A. (2017) Is Restorative Justice a Part of the Colombian Transitional Justice Puzzle? Restorative Justice: An International Journal, 5(2), 293-308.

Stokkom, B. van (2016) Positieve veiligheid en het verlangen naar gemeenschap. Naar een criminologie van vredesopbouw. Tijdschrift over Cultuur en Criminaliteit, 6(3), 116-125.

Walgrave, L. (2015) Binnenlands terrorisme. Een uitdaging voor herstelrecht. Tijdschrift voor Herstelrecht, 15(2), 38-46.

Walgrave, L. (2016) Restorative Justice is Not a Panacea Against All Social Evils. In: I. Aertsen \& B. Pali (eds.), Critical Restorative Justice (p. 95-110). Oxford and Portland: Hart.

Willis, R. (2020) 'Let's talk about it': why social class matters to restorative justice. Criminology and Criminal Justice, 20(2), 187-206.

Zernova, M. (2017) Restorative Justice in the Basque Peace Process: Some Experiments and Their Lessons. Contemporary Justice Review, 20(3), 363-391.

Zernova, M. (2019) Restorative justice in the aftermath of politically-motivated violence: the Basque experience. Critical Studies on Terrorism, 12(4), 649-672. 